\title{
Peningkatan Status Mutu Sungai Cimahi dengan Penyusunan Rencana Induk Sistem Pengolahan Air Limbah Domestik
}

\author{
Muhammad Viqi Rafianto ${ }^{1}$, Eka Wardhani $^{2}$ \\ ${ }^{1,2}$ Jurusan Teknik Lingkungan, Institut Teknologi Nasional (Itenas), Bandung \\ *Koresponden email: viqirafianto06@gmail.com, ekawardhani08@gmail.com
}

Diterima : 23 Maret 2021

Disetujui: 5 April 2021

\begin{abstract}
Population growth greatly influences changes in land use, and the Cimahi Watershed (DAS) is also experiencing these changes. The change in land use has resulted in reduced water quality in the Cimahi River. Water pollution in the Cimahi River is greatly influenced by the discharges from the Cimahi River watershed facilities. This research identifies a master plan for wastewater management in the Cimahi watershed to improve water quality of the Cimahi River and establishes a Domestic Wastewater Management System (SPALD) in the Cimahi Watershed region. Wastewater management provisions are regulated by PermenPUPR No. 4 of 2017 through a series of screening. As a result of a series of screenings conducted for the Cimahi watershed, which consists of seven sub-districts, only one subdistrict can use the Centralized SPALD, namely Cimahi Village. Two sub-districts of the Cimahi watershed did not meet the population density selection criteria, and five sub-districts within the Cimahi watershed did not meet the criteria for a depth review. Follow-up screening, such as groundwater permeability, ability to fund, and slope of the land for all urban villages met the screening criteria.
\end{abstract}

Keywords: Cimahi river, pollutant index, wastewater treatment system, domestic waste, watershed

\begin{abstract}
Abstrak
Pertumbuhan penduduk sangat mempengaruhi perubahan tata guna lahan, perubahan tata guna lahan dialami juga oleh Daerah Aliran Sungai (DAS) Cimahi. Perubahan tata guna lahan tersebut mengakibatkan penurunan kualitas air Sungai Cimahi. Pencemaran air Sungai Cimahi sangat dipengaruhi oleh buangan dari pemukiman di DAS Cimahi. Penelitian ini menentukan rencana induk pengelolaan air limbah DAS Cimahi guna memperbaiki kualitas air Sungai Cimahi dan menetapkan Sistem Pengelolaan Air Limbah Domestik (SPALD) pada kelurahan DAS Cimahi. Ketentuan pengelolaan air limbah diatur oleh PermenPUPR No. 4 tahun 2017 melalui serangkaian penapisan. Hasil dari serangkaian penapisan yang dilakukan untuk DAS Cimahi yang terdiri dari tujuh kelurahan hanya satu kelurahan saja yang dapat menggunakan SPALD Terpusat yaitu Kelurahan Cimahi. Dua kelurahan DAS Cimahi tidak memenuhi kriteria penapisan kepadatan penduduk, dan lima kelurahan DAS Cimahi tidak memenuhi kriteria penapisan kedalaman muka air tanah. Penapisan lanjutannya yaitu permeabilitas air tanah, kemampuan pembiayaan, dan kemiringan tanah untuk seluruh kelurahan memenuhi kriteria penapisan.

Kata Kunci: Sungai Cimahi, indeks pencemar, sistem pengolahan air limbah, limbah domestik, daerah aliran sungai
\end{abstract}

\section{Pendahuluan}

Daerah Aliran Sungai (DAS) Cimahi dengan sungai utamanya yaitu Sungai Cimahi, membentang sepanjang $7 \mathrm{~km}$ dan bermuara di Sungai Citarum, Kabupaten Bandung dan kabupaten Bandung Barat. Sungai Cimahi alirannya melewati 3 kecamatan di Kota Cimahi diantaranya yaitu Kecamatan Cimahi Utara sebagai hulu Sungai Cimahi di Kota Cimahi, Cimahi Tengah sebagai bagian tengah Sungai Cimahi di Kota Cimahi, dan Cimahi Selatan yang merupakan bagian hilir Sungai Cimahi di Kota Cimahi dan bermuara di Sungai Citarum. Berdasarkan parameter Status Mutu, Sungai Cimahi termasuk kategori sungai tercemar berat, pencemar bersumber sebagian besar dari buangan limbah rumah tangga. Seiring peningkatan jumlah penduduk, industri dan fasilitas umum, membuat daerah DAS Cimahi mengalami perubahan tata guna lahan yang mengakibatkan DAS Cimahi mengalami pendangkalan, penurunan kualitas air [1] [2].

Waduk Saguling merupakan waduk yang membendung air dari aliran Sungai Citarum, maka pencemaran kualitas air Sungai Citarum dan anak sungainya akan mempengaruhi operasional dan kualitas Waduk Saguling [5] [6] [7]. Terjadinya pencemaran berat diakibatkan akumulasi beberapa zat pencemar seperti logam berat pada sedimen Waduk Saguling dan ini mengganggu fungsi Waduk Saguling yaitu 
irigasi, sumber air baku dan area budidaya perikanan [8] [9] [10]. Penanganan terjadinya pencemaran kualitas air Sungai Cimahi dapat dilakukan dengan meningkatkan pelayanan pengelolaan air limbah domestik, dimana pelayanan dilakukan di DAS Cimahi.

Tujuan dari kajian ini yaitu menggambarkan keadaan mutu air dari Sungai Cimahi dimana Sungai Cimahi merupakan anak Sungai Citarum. Data yang digunakan yaitu data Baku Mutu pada 3 bulan di Tahun 2019. Kajian mengenai nilai mutu Sungai Cimahi dilakukan di bagian hulu Sungai Cimahi, bagian tengah Sungai Cimahi serta bagian hilir Sungai Cimahi. Data yang akan dianalisis diperoleh dari DLH Kota Cimahi. Berdasarkan kondisi mutu air Sungai Cimahi lalu dilakukan upaya penangan berupa penentuan Sistem Pengolahan Air Limbah Domestik di Kawasan DAS Cimahi [3] [5].

\section{Metode Penelitian}

Dinas Lingkungan Hidup Kota Cimahi pada Tahun 2019 telah melakukan pemantauan kondisi Sungai Cimahi dan dilakukan secara 3 kali yaitu pada Bulan April, Bulan September dan Bulan Desember. Pemantauan dilakukan di 3 titik, 3 titik tersebut menggambarkan kondisi hulu, tengah, dan hilir Sungai Cimahi letak lokasi titik pemantauan di sajikan pada Gambar 1 [2].

Metode menghitung mutu air Sungai Cimahi dapat dilakukan sesuai Kepmen LH 115/2003, nilai mutu sungai yang digunakan merupakan nilai Indeks Pencemar (IP) dan kategori nilai mutu dapat dilihat pada Tabel 1. Rumus untuk menghitung nilai dari IP dirumuskan pada persamaan 1, berdasarkan rumus persamaan 1 nilai IP merupakan $\mathrm{Ci} / \mathrm{Lij}$, Ci merupakan nilai konsentrasi dari kualitas air yang diambil dari contoh uji air di titik lokasi, sedangkan Lij yaitu nilai konsentrasi dari parameter tertentu yang diatur atau ditentukan oleh baku mutu air sungai. Nilai $\mathrm{M}$ yaitu nilai maksimum dari konsentrasi terukur dan $\mathrm{R}$ yaitu rata-rata dari konsentrasi terukur [1].

$$
P I_{j}=\sqrt{\frac{\left(C_{i} / L_{i j}\right)_{M}^{2}+\left(C_{i} / L_{i j}\right)_{R}^{2}}{2}} \quad \text { Tabel 1. Nilai Indeks Pencemar Sungai }
$$

\begin{tabular}{cc}
\hline Indeks & Penilaian \\
\hline $0 \leqslant$ IP $\leqslant 1$ & Sesuai Baku Mutu \\
$1 \leqslant \mathrm{IP} \leqslant 5$ & Sungai Tercemar Ringan \\
$5 \leqslant \mathrm{IP} \leqslant 10$ & Sungai Tercemar Sedang \\
$\mathrm{IP} \geqslant 10$ & Sungai Tercemar Berat \\
\hline \multicolumn{2}{c}{ Sumber: Kepmen LH $115 / 2003$}
\end{tabular}

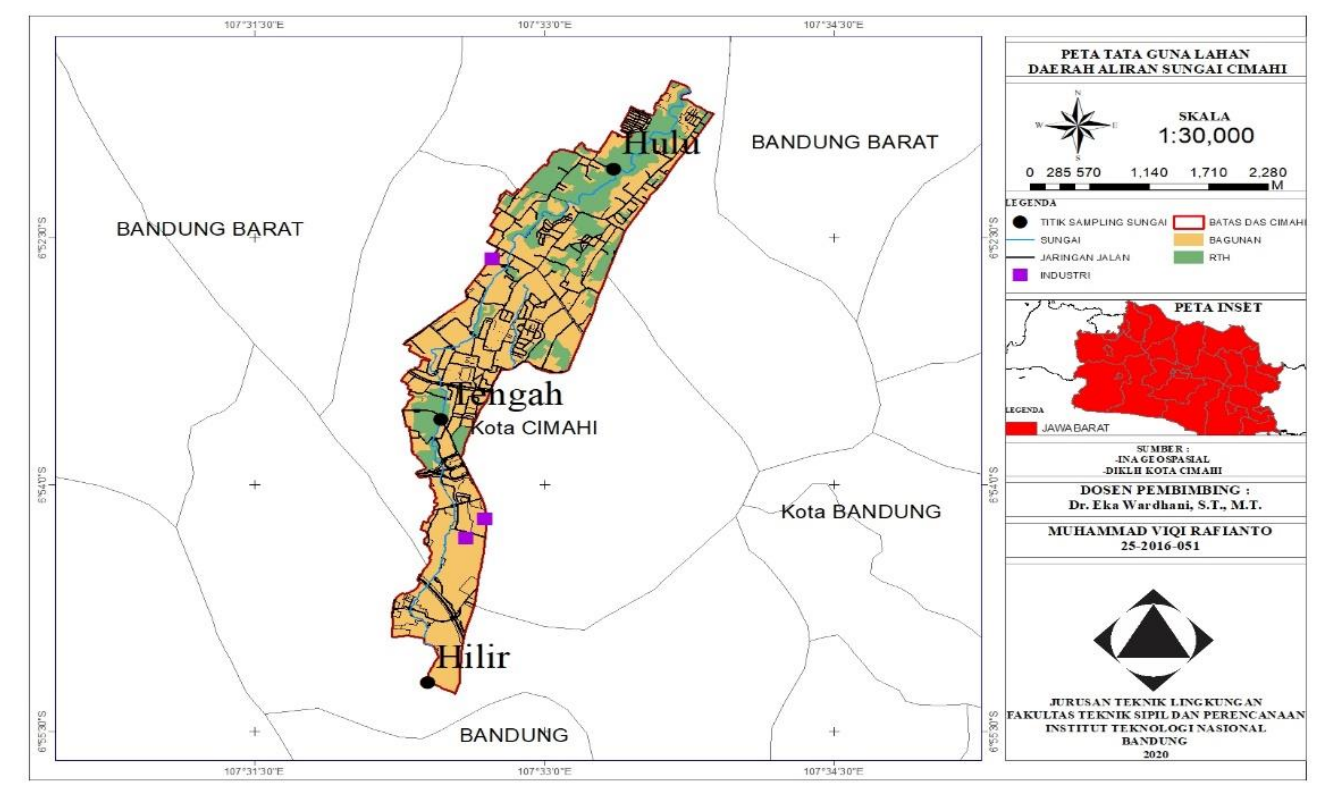

Gambar 1. Lokas titik pengambilan air sampel Sungai Cimahi Sumber: Hasil pengolahan data (2021)

Cara perhitungan IP harus sesuai dengan Kepmen LH 115/2003, terdapat beberapa ketentuan dalam menghitung IP yaitu: 
1. Ketika nilai dari suatu konsentrasi menurun dan menyatakan meningkatnya pencemaran, misal Dissolve Oxygen (DO) pertama yaitu tentukan nilai konsentrasi maksimum $\mathrm{C}_{\mathrm{im}}(\mathrm{DO}$, nilai dari $\mathrm{C}_{\mathrm{im}}$ yaitu nilai DO jenuh). Rumus untuk menghitung nilai $\mathrm{C}_{\mathrm{i}} / \mathrm{L}_{\mathrm{ij}}$ digantikan oleh nilai $\mathrm{C}_{\mathrm{i}} / \mathrm{L}_{\mathrm{ij}}$ hasil menjadi:

$$
\left(\mathrm{C}_{\mathrm{i}} / \mathrm{L}_{\mathrm{ij}}\right)_{\text {baru }}=\frac{\mathrm{C}_{\mathrm{im}}-\mathrm{C}_{\mathrm{ihasil}} \text { pengukuran }}{\mathrm{C}_{\mathrm{im}}-\mathrm{L}_{\mathrm{ij}}}
$$

2. Saat nilai $\mathrm{L}_{\mathrm{ij}}$ memiliki rentang

$$
\begin{aligned}
& \text { - Untuk } \mathrm{C}_{\mathrm{i}} \leq \mathrm{L}_{\mathrm{j}} \text { rata-rata } \\
& \qquad\left(\mathrm{C}_{\mathrm{i}} / \mathrm{L}_{\mathrm{ij}}\right)_{\text {baru }}=\frac{\left[\mathrm{C}_{\mathrm{i}}-\left(\mathrm{L}_{\mathrm{ij}}\right)_{\text {rata-rata }}\right]}{\left(\left(\mathrm{L}_{\mathrm{ij}}\right)_{\text {minimum }}-\left(\mathrm{L}_{\mathrm{ij}}\right)_{\text {rata-rata }}\right)}
\end{aligned}
$$

- Untuk $\mathrm{C}_{\mathrm{i}}>\mathrm{L}_{\mathrm{ij}}$ rata-rata

$$
\left(\mathrm{C}_{\mathrm{i}} / \mathrm{L}_{\mathrm{ij}}\right)_{\text {baru }}=\frac{\left[\mathrm{C}_{\mathrm{i}}-\left(\mathrm{L}_{\mathrm{ij}}\right)_{\text {rata-rata }}\right]}{\left(\left(\mathrm{L}_{\mathrm{ij}}\right)_{\text {maksimum }}-\left(\mathrm{L}_{\mathrm{ij}}\right)_{\text {rata-rata }}\right)}
$$

3. Memastikan nilai $\left(\mathrm{C}_{\mathrm{i}} / \mathrm{L}_{\mathrm{ij}}\right)$ jika keraguan timbul karena nilai berdekatan dengan nilai acuan 1,0 , misal $C_{1} / L_{1 j}=0,9$ dan $C_{2} / L_{2 j}=1,1$ dan terdapat selisih nilai yang sangat besar, misal $C_{3} / L_{3 j}=5,0$ dan $\mathrm{C}_{4} / \mathrm{L}_{4 \mathrm{j}}=10,0$. Pada contoh tersebut nilai untuk mengategorikan kerusakan yang timbul di badan air terdapat kesulitan, maka dapat diatasi dengan cara sebagai berikut:

- $\quad$ Nilai dari $\left(\mathrm{C}_{\mathrm{i}} / \mathrm{L}_{\mathrm{ij}}\right)$ tetap jika nilai lebih kecil dari 1,0.

- Nilai $\left(\mathrm{C}_{\mathrm{i}} / \mathrm{L}_{\mathrm{ij}}\right)$ baru jika nilai $\left(\mathrm{C}_{\mathrm{i}} / \mathrm{L}_{\mathrm{ij}}\right)$ hasil pengukuran lebih besar dari 1,0 dan dapat dilihat pada persamaan 5

$$
\left(\mathrm{C}_{\mathrm{i}} / \mathrm{L}_{\mathrm{ij}}\right) \text { baru }=1,0+\mathrm{P} \cdot \log \left(\mathrm{C}_{\mathrm{i}} / \mathrm{L}_{\mathrm{ij}}\right) \text { hasil pengukuran (5) }
$$

Nilai $\mathrm{P}$ merupakan konstanta yang digunakan dengan bebas sesuai keadaan hasil pengamatan kondisi sungai tersebut (biasanya digunakan nilai 5) [14].

Upaya pengendalian pencemaran yang dilakukan dengan menentukan jenis SPALD mengacu pada penapisan PermenPUPR No.4/2017 yang disajikan pada Gambar 2. Jenis SPALD yang dihasilkan dapat berupa SPALD-T dan/atau SPALD-S yang disesuaikan dengan hasil penapisan. Kemudian setelah ditentukannya jenis SPALD maka tahap selanjutnya akan dilakukan pembuatan jalur pelayanan sesuai SPALD yang diterapkan dengan mempertimbangkan peta prioritas pelayanan SPALD.

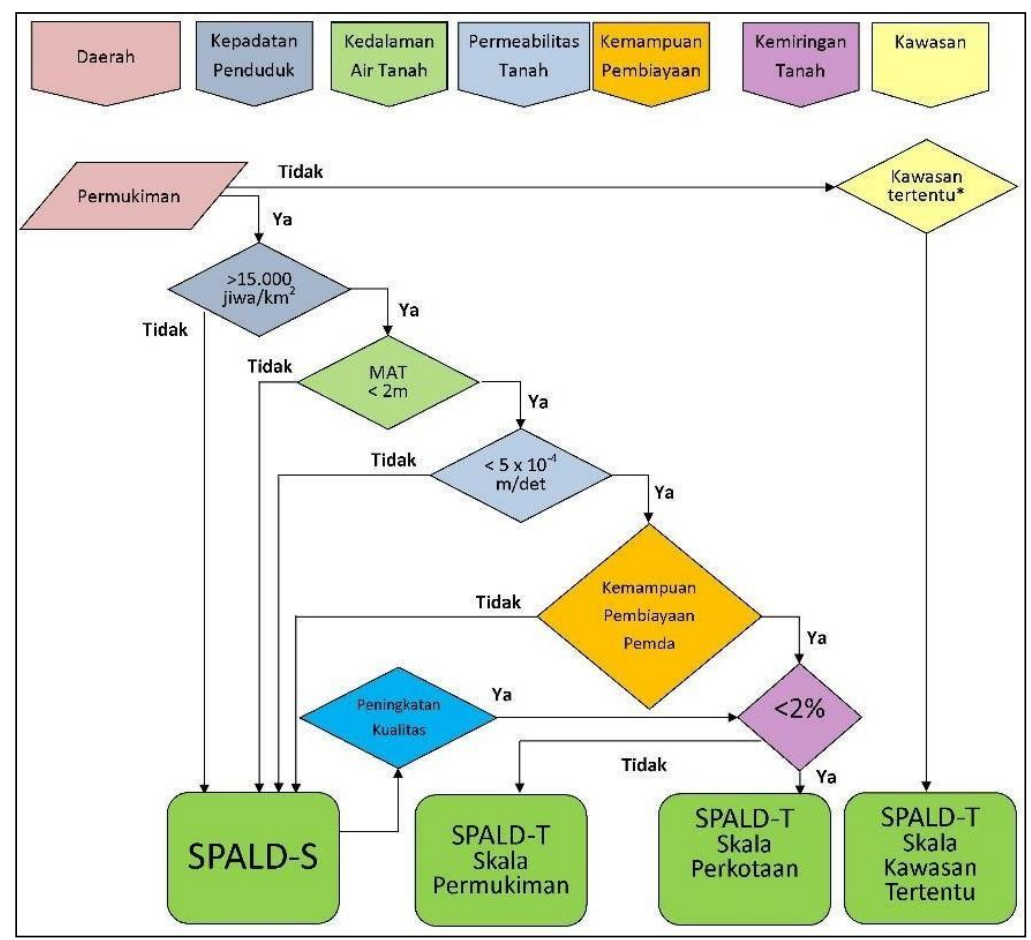

Gambar 2. Diagram penapisan pemilihan jenis SPALD Sumber: PermenPUPR No.4 Tahun 2017 [17] 


\section{Hasil dan Pembahasan}

Sungai Cimahi memiliki panjang $7 \mathrm{~km}$ dan juga sungai yang bermuara di Sungai Citarum. Daerah Aliran Sungai Cimahi melewati wilayah 3 kecamatan dan 7 kelurahan DAS Cimahi memiliki luas \pm 557,6 Ha. Bagian hulu sungai Cimahi merupakan ruang terbuka hijau, bagian tengah dan hilir didominasi pemukiman padat. Peningkatan jumlah penduduk mengakibatkan DAS Cimahi mengalami perubahan fungsi dan tata guna lahannya sehingga mempengaruhi kualitas dan kuantitas air Sungai Cimahi.

Data nilai konsentrasi yang digunakan merupakan hasil pengukuran yang dilakukan oleh DLH Cimahi di bulan April, September, dan Desember tahun 2019. Kemudian data tersebut dibandingkan dengan baku mutu Peraturan Pemerintah Nomor 22 Tahun 2021 (PP22/2021) tentang Penyelenggaraan Perlindungan Dan Pengelolaan Lingkungan Hidup, yang tertera pada lampiran 6 dengan baku mutu air kelas 2. Penggunaan baku mutu kelas 2 karena sampai saat ini Sungai Cimahi belum ditetapkan kelasnya. Berdasarkan hasil analisis terdapat 15 parameter yang melebihi baku mutu, yaitu Total Dissolved Solid (TDS), Total Suspended Solid (TSS), Biochemical Oxygen Demand (BOD5), Chemical Oxygen Demand (COD), DO, Phosphat, Pb, Zn, Sulfida, NO2-N, Klorin Bebas, Total Coliform, Fecal Coliform, minyak dan lemak, fenol, deterjen Methylen Blue Active Surfactant (MBAS). Parameter kualitas air yang bersumber dari buangan rumah tangga yaitu untuk parameter BOD5, COD, dan parameter mikrobiologi berupa Total Coliform dan Fecal Coliform melebihi baku mutu untuk 3 kali pengukuran di bulan April, September, dan Desember tahun 2019.

Indeks Pencemar Sungai Cimahi pada bulan April 2019 dari hulu hingga hilir termasuk kedalam kategori tercemar berat. Angka Indeks Pencemar tertinggi berada pada bagian hilir sungai Cimahi yaitu 16,797, lalu bagian tengah sebesar 16.793, serta bagian hulu 16,722. Parameter Total Coliform dan Fecal Coliform sangat mempengaruhi angka Indeks Pencemar pada bulan April 2019. Indeks Pencemar Sungai Cimahi pada bulan September 2019 dari hulu hingga hilir termasuk ke dalam kategori tercemar berat. Angka Indeks Pencemar tertinggi berada pada bagian hilir sungai Cimahi yaitu 21,986, lalu bagian tengah sebesar 17,981, serta bagian hulu 14,135. Parameter Total Coliform dan Fecal Coliform sangat mempengaruhi angka Indeks Pencemar pada bulan September 2019. Indeks Pencemar Sungai Cimahi pada bulan Desember 2019 dari hulu hingga hilir termasuk kedalam kategori tercemar berat. Angka Indeks Pencemar tertinggi berada pada bagian hilir sungai Cimahi yaitu 22,507, lalu bagian tengah sebesar 16,299, serta bagian hulu 15,454. Parameter Total Coliform dan Fecal Coliform sangat mempengaruhi angka Indeks Pencemar pada bulan Desember 2019.

Angka Indeks Pencemar untuk ke 3 bulan, yaitu April, September, dan Desember tahun 2019 mempunyai kesamaan yaitu Nilai Indeks Pencemar meningkat dari hulu hingga hilir karena penggunaan lahan daerah aliran sungai Cimahi yang didominasi oleh pemukiman. Nilai Indeks Pencemar paling tinggi merupakan parameter Total Coliform dan Fecal Coliform, tingginya parameter mikrobiologi tersebut menjelaskan limbah rumah tangga merupakan salah satu sumber pencemar dominan di Sungai Cimahi. Nilai rata rata Indeks Pencemar Sungai Cimahi yang paling tinggi ada pada bulan Desember 2019 bagian hilir yaitu 22,507 dan paling rendah ada pada bulan September 2019 yaitu 14,13.

Penentuan sistem pengendalian pencemaran domestik di DAS Cimahi dengan mengacu pada kriteria yang telah diatur oleh Permen PUPR No. 4/2017 melalui serangkaian analisa penapisan di DAS Cimahi. Kriteria yang diatur Permen PUPR No. 4/2017 dalam penentuan jenis sistem pengelolaan sistem pengelolaan air limbah domestik akan dibandingkan dengan kondisi eksisting daerah perencanaan yaitu DAS Cimahi. Perbandingan ini akan menghasilkan analisa penentuan SPAL-D setiap kelurahan yang termasuk ke dalam DAS Cimahi.

\section{Kepadatan Penduduk}

Kepadatan penduduk adalah langkah awal saat melakukan penapisan dan merupakan faktor yang sangat penting dalam penentuan jenis sistem pengelolaan air limbah domestik baik SPALD Setempat atau SPALD Terpusat. Ketentuan untuk kepadatan penduduk jika menggunakan SPALD-T kepadatan penduduk di kelurahan DAS Cimahi harus lebih besar dari 150 jiwa/ha. Jika ketentuan untuk kepadatan penduduk terpenuhi maka dapat melanjutkan penapisan terhapar SPALD-T, namun jika kelurahan di DAS Cimahi memiliki kepadatan yang lebih kecil dari $150 \mathrm{jiwa} / \mathrm{ha}$ maka pengelolaan air limbah domestik menggunakan SPAL-S. Kepadatan penduduk yang terdapat di DAS Cimahi dapat dilihat pada Tabel 2 dan mengenai kepadatan penduduk dapat dilihat pada Gambar 9. 
Tabel 2. Kepadatan penduduk di DAS Cimahi

\begin{tabular}{llr}
\hline No & Kelurahan & $\begin{array}{l}\text { Kepadatan penduduk } \\
\text { (jiwa/ha) }\end{array}$ \\
\hline 1. & Cibabat & 200 \\
2. & Citeureup & 117 \\
3. & Cimahi & 208 \\
4. & Karang Mekar & 150 \\
5. & Cigugur Tengah & 212 \\
6. & Baros & 83 \\
7. & Utama & 97 \\
\hline & Sumber: Hasil pengolahan data (2021)
\end{tabular}

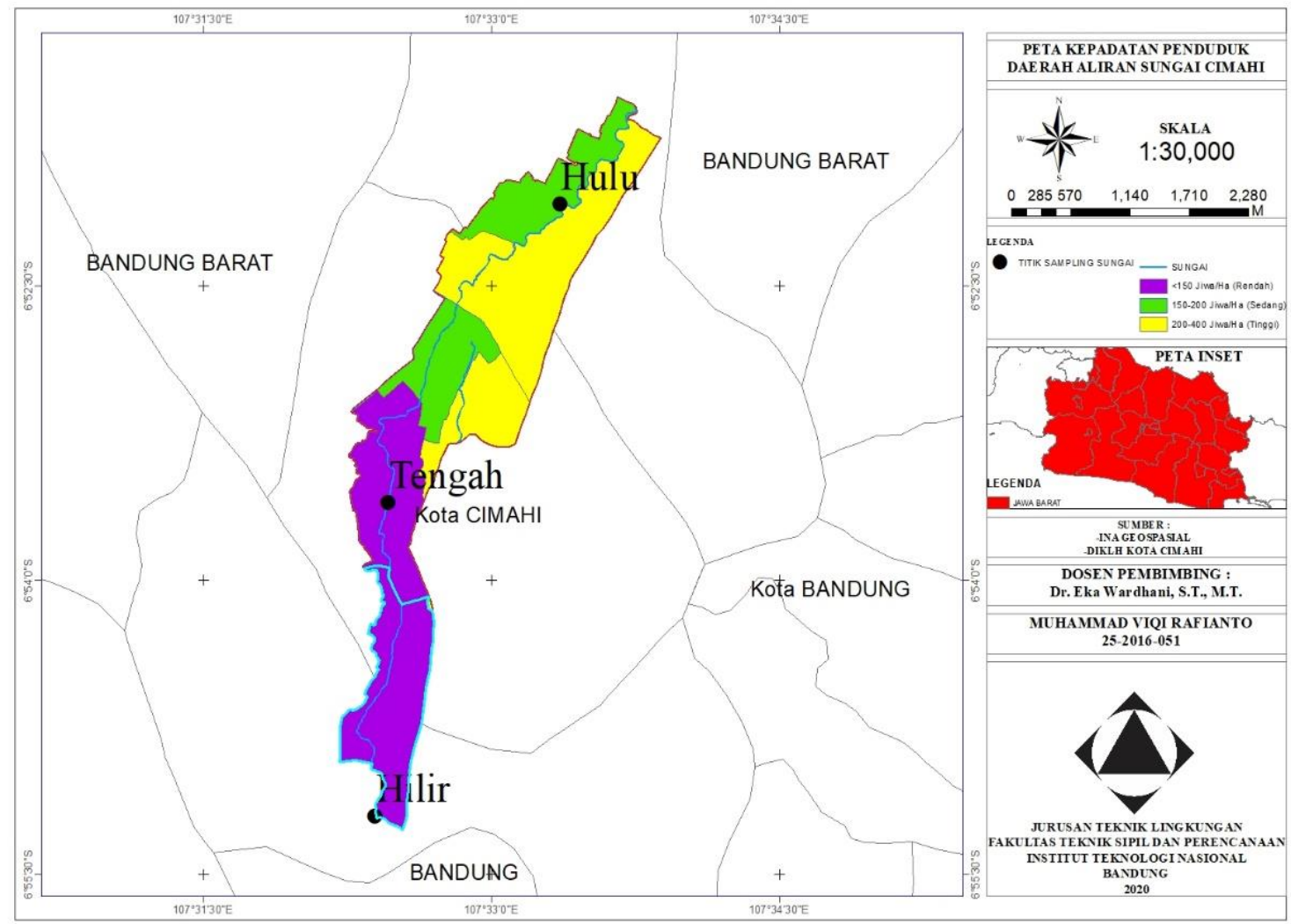

Gambar 3. Kepadatan penduduk DAS Cimahi Sumber: Hasil pengolahan data (2021)

Berdasarkan Tabel 2 kepadatan tertinggi berada di Kelurahan Cigugur Tengah dengan kepadatan 212 jiwa/ha kemudian diikuti Kelurahan Cimahi 208 jiwa/ha, Kelurahan Cibabat sebesar 200 jiwa/ha, Kelurahan Karang Mekar sebesar 150 jiwa/ha, Kelurahan Citeureup sebesar 117 jiwa/ha, Kelurahan Utama sebesar 97 jiwa/ha, Kelurahan Baros sebesar 83 jiwa/ha. Pengelolaan air limbah berdasarkan kepadatan penduduk di DAS Cimahi menggunakan SPALD-T untuk 4 kelurahan, yaitu Kelurahan Cigugur Tengah, Cimahi, Cibabat, Karang Mekar dan menggunakan SPALD-S ada 3 kelurahan yaitu Citeurep, Utama, dan Baros.

\section{Kedalaman Muka Air Tanah}

Kedalaman muka air tanah yang diperbolehkan pada PermenPUPR No.4/2017 untuk menggunakan SPALD-T harus kurang dari 2 meter jika kedalaman muka air tanah lebih besar maka pengelolaan air limbah menggunakan SPALD-S. Tingkat kedalaman muka air tanah di beberapa kelurahan pada DAS Cimahi terdapat beberapa kategori yaitu aman, rawan, dan kritis, sementara untuk kategori aman ada dua kedalaman muka air tanahnya yaitu <25m dan 25m, untuk kategori rawan 25-35m dan kategori kritis 35$55 \mathrm{~m}$. Mengacu pada peraturan menteri tersebut maka DAS Cimahi terdapat beberapa kelurahan yang mempunyai muka air tanah aman $<25 \mathrm{~m}$ dianggap memenuhi kriteria untuk muka air tanah yaitu kelurahan Cimahi dan Citeureup. Sementara kelurahan yang lainnya menggunakan SPALD-S. Peta potensi air tanah DAS Cimahi dapat dilihat pada Gambar 4. 


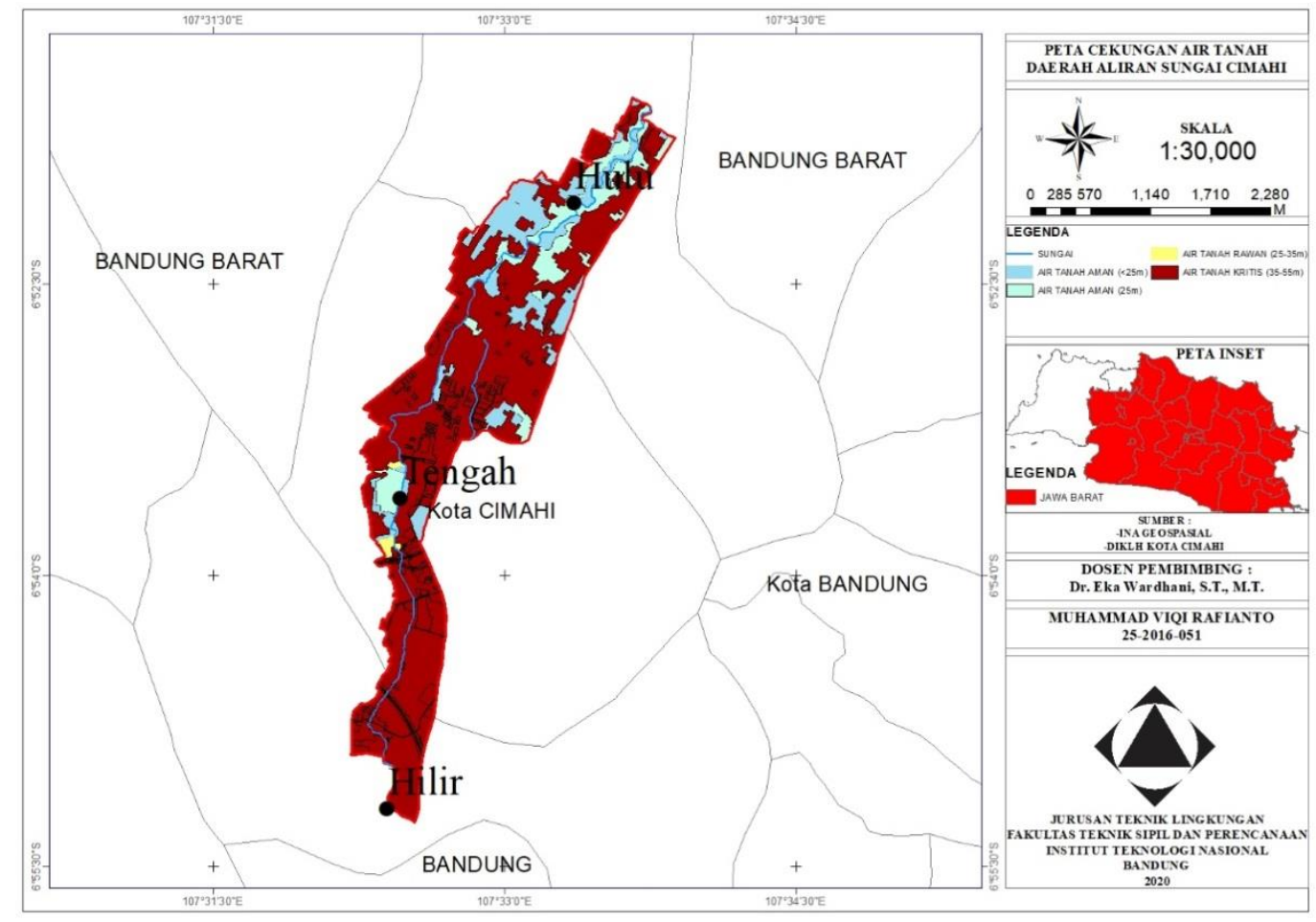

Gambar 4. Kondisi Air Tanah penduduk DAS Cimahi Sumber: Hasil pengolahan data (2021)

\section{Permeabilitas Tanah}

Daerah Aliran Sungai Cimahi hampir seluruhnya merupakan jenis tanah lempung lanau dan beberapa berjenis tanah batuan tufa. Tanah lempung lanau memiliki rentang permeabilitas $10^{-6}-10^{-4}$ $\mathrm{m} /$ detik [3]. Persebaran jenis tanah di DAS Cimahi dapat dilihat pada Gambar 5. Ketentuan permeabilitas tanah yang diatur PermenPUPR No.4/2017 yaitu $<5 \times 10^{-4} \mathrm{~m} /$ detik sehingga seluruh kelurahan pada DAS Cimahi dapat menggunakan SPALD-T.

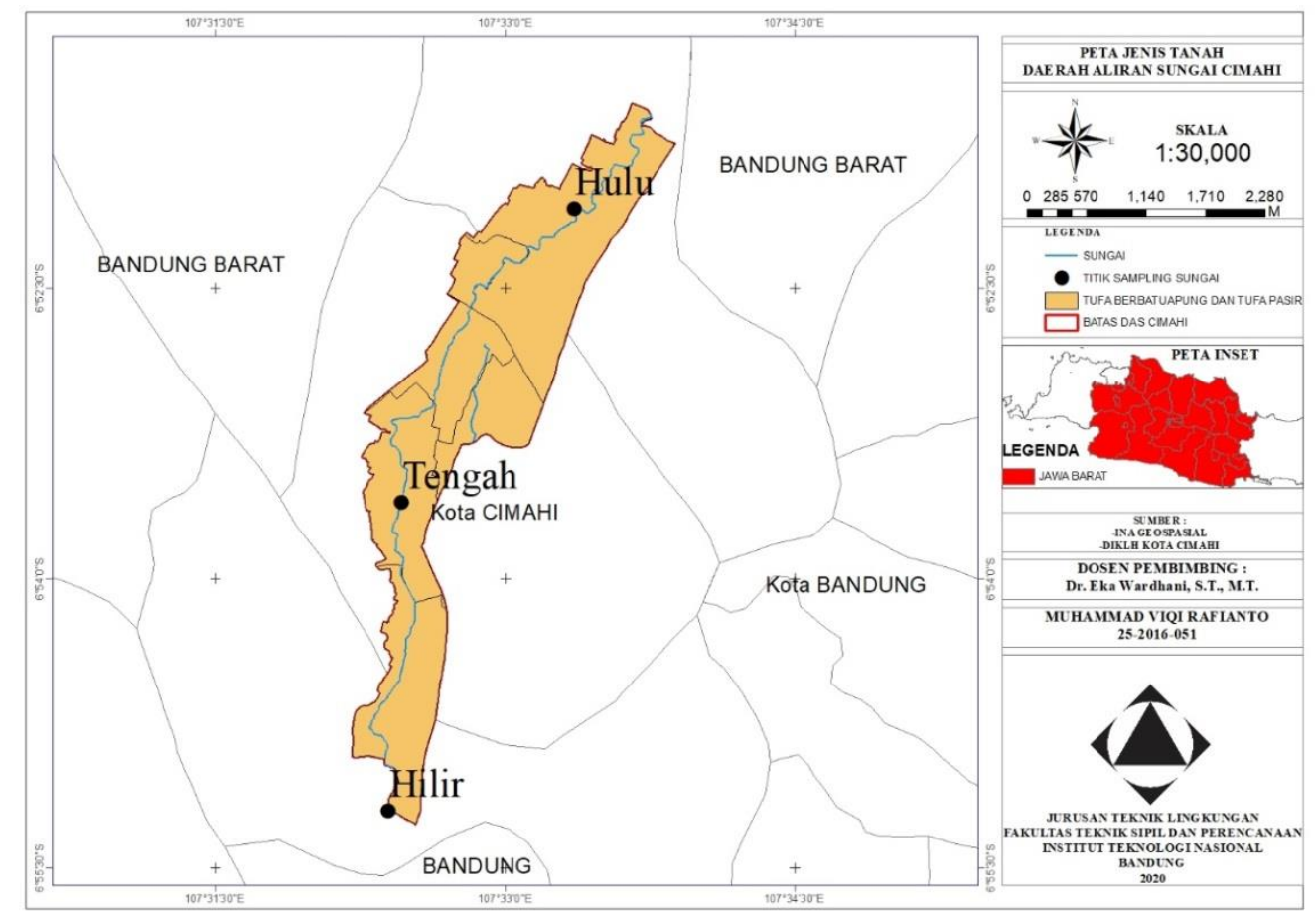

Gambar 5. Peta Jenis tanah DAS Cimahi Sumber: Hasil pengolahan data (2021) 


\section{Kemampuan Pembiayaan}

Ketentuan PermenPUPR No.4/2017 untuk kemampuan pembiayaan harus dipenuhi karena tidak sedikit biaya untuk menggunakan SPALD-T dimana biaya tersebut tinggi untuk pemasangan perpipaan SPALD. DAS Cimahi memenuhi persyaratan dengan menggunakan SPALD-T dimana Pemerintah Kota Cimahi sudah membuat anggaran pengelolaan air limbah domestik.

\section{Kemiringan Tanah}

Kriteria kemiringan tanah yang diatur PermenPUPR No.4/2017 yaitu nilainya harus lebih besar dari dua persen menggunakan SPALD-T. Tujuh kelurahan yang termasuk di dalam DAS Cimahi berada pada kemiringan 0-8\% yang relatif datar. Maka dari itu, sistem pengelolaan limbah domestik untuk kriteria kemiringan tanah yang digunakan di DAS Cimahi untuk seluruh kelurahan adalah SPALD-T. Peta kemiringan lereng DAS Cimahi disajikan pada Gambar 6 dan Gambar 7.

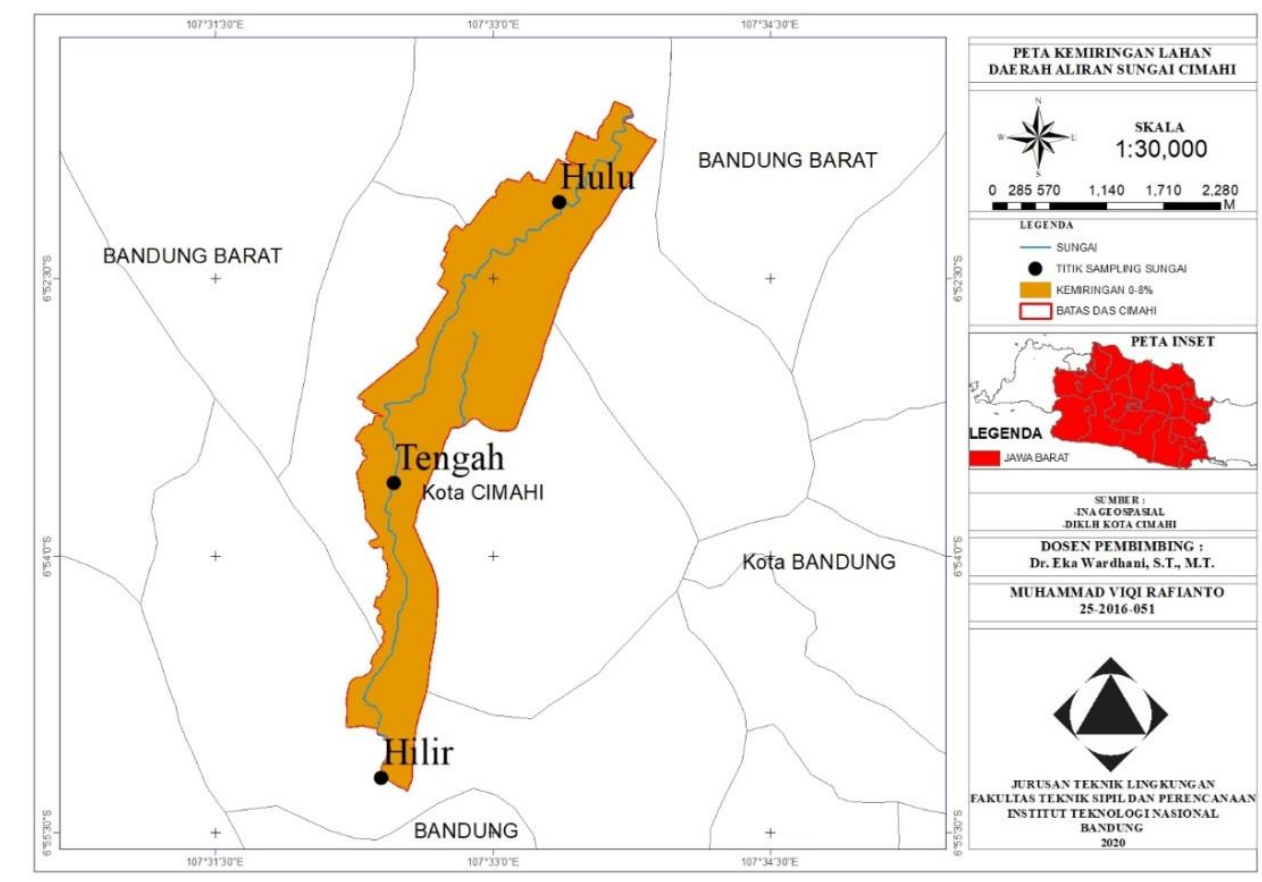

Gambar 6. Peta kemiringan lahan DAS Cimahi Sumber: Hasil pengolahan data (2021)

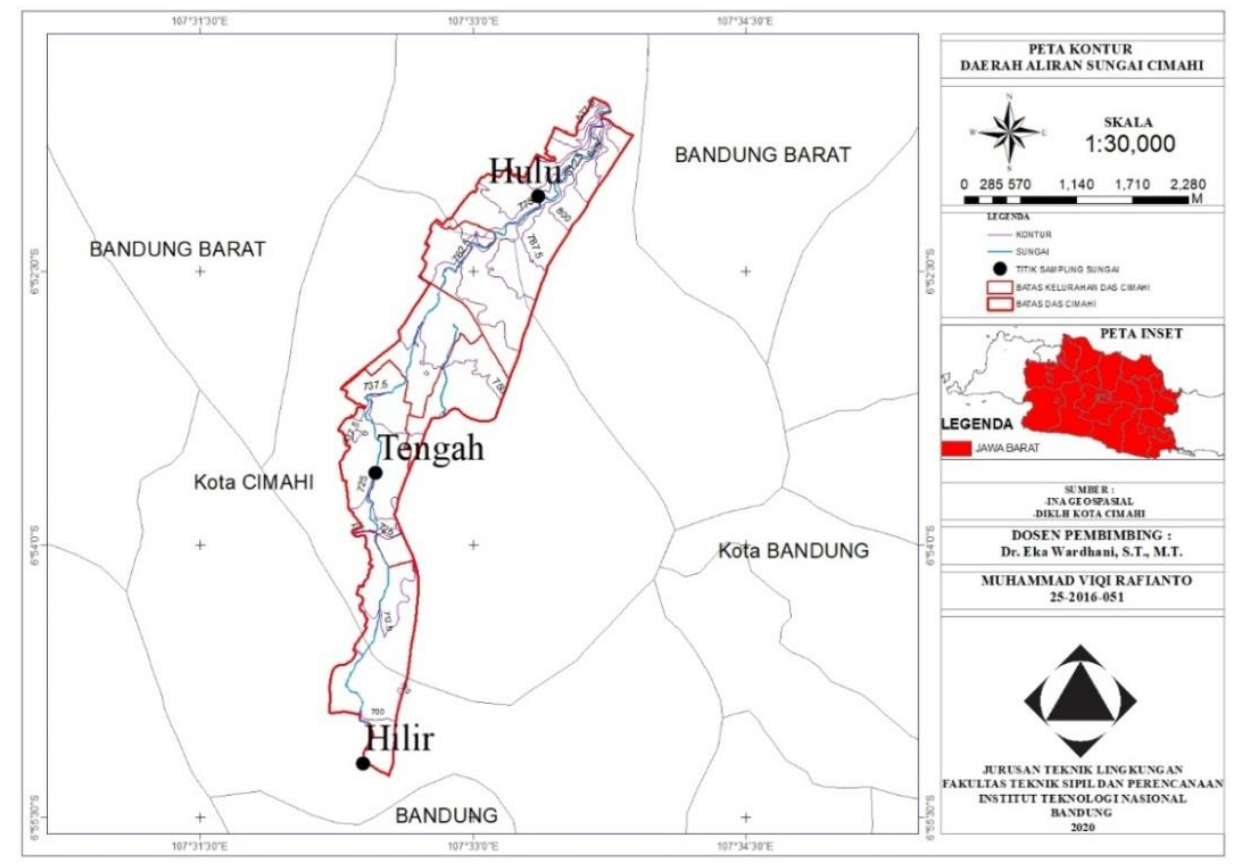

Gambar 7. Peta kontur lahan DAS Cimahi Sumber: Hasil pengolahan data (2021) 
Ada beberapa analisa daftar penapisan yang memenuhi dan tidak memenuhi persyaratan untuk aturan SPALD-T di setiap kelurahan yang termasuk DAS Cimahi. Indikator permeabilitas tanah, kemampuan pembiayaan dan kemiringan tanah seluruh kelurahan memenuhi persyaratan. Sedangkan, pada analisa daftar penapisan kepadatan penduduk di DAS Cimahi terdapat 4 kelurahan yang memenuhi yaitu kelurahan Cimahi, Cigugur Tengah, Cibabat, dan Karang Mekar sedangkan Kelurahan Citeureup, Utama, dan Baros tidak memenuhi persyaratan kepadatan penduduk untuk analisa daftar penapisan selanjutnya. Analisa daftar penapisan selanjutnya kedalaman muka air tanah di 2 kelurahan yaitu kelurahan Cimahi dan Citeureup mempunyai muka air tanah aman karena $<25$ m dianggap layak untuk syarat muka air tanah, dan dapat dilakukan analisa daftar penapisan lanjutan.

Kriteria PermenPUPR No.4/2017 untuk menentukan SPALD dapat dilihat pada Gambar 2 yaitu diagram alir pemilihan jenis SPALD dapat diketahui bahwa DAS Cimahi hanya terdapat satu kelurahan yang memenuhi semua kriteria untuk SPALD-T yaitu Kelurahan Cimahi, sementara untuk enam kelurahan lainnya menggunakan SPALD-S. Peta penentuan SPALD di sajikan pada Gambar 8.

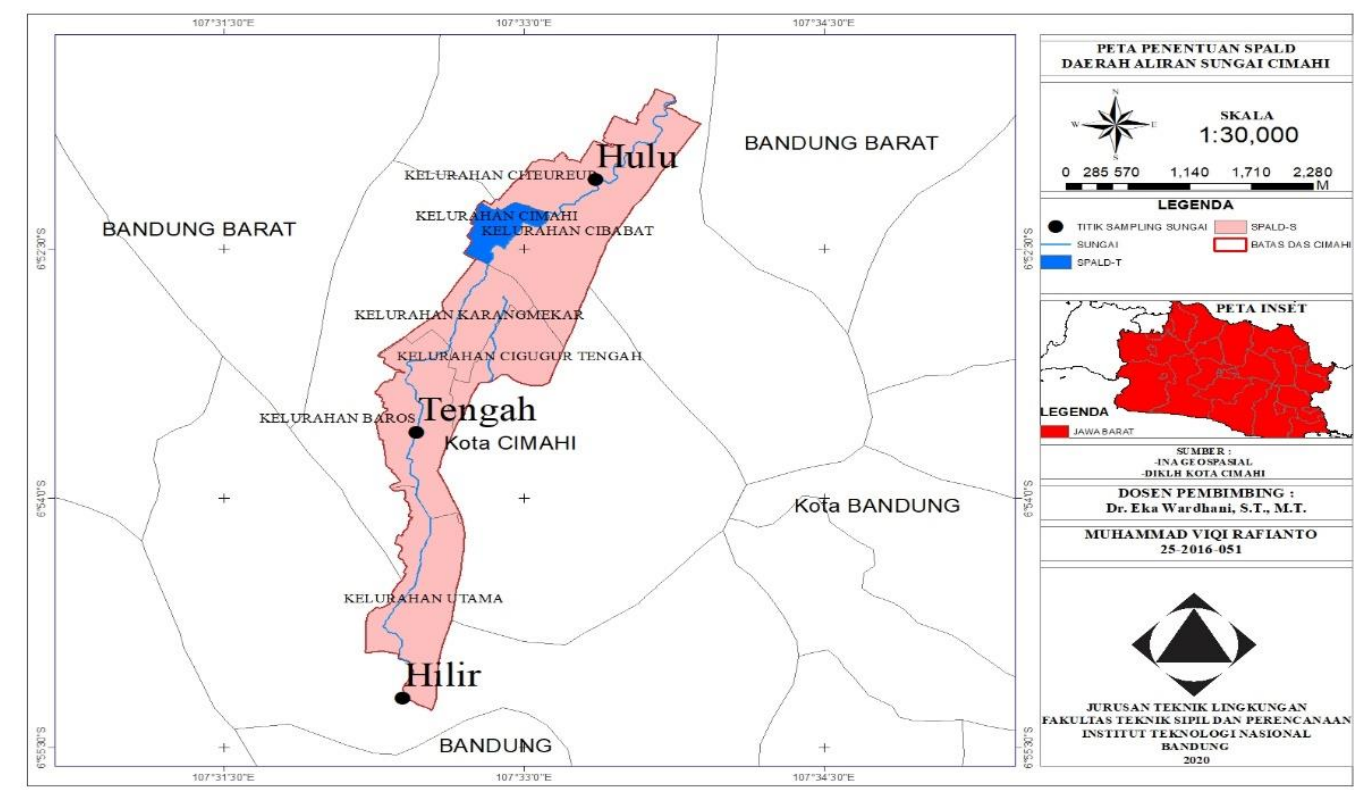

Gambar 8. Peta kontur lahan DAS Cimahi

Sumber: Hasil pengolahan data (2021)

\section{Kesimpulan}

Sungai Cimahi menunjukkan tingkat pencemaran yang tinggi dimana dari status mutu dengan metode IP diketahui bahwa Sungai Cimahi selama 3 bulan di tahun 2019 telah termasuk kedalam kategori tercemar berat baik dari hulu, tengah, hingga hilir. Nilai IP tertinggi dihasilkan dari nilai konsentrasi mikroorganisme Fecal Coliform dan Total Coliform hal ini dikaji lebih dalam pada perhitungan BP. Maka dari itu perlu adanya upaya penanganan pengelolaan air limbah domestik. Upaya penanganan dapat berupa menentukan SPALD Kawasan DAS Cimahi sehingga diharapkan mampu menurunkan konsentrasi pencemar dan memperbaiki kualitas air Sungai Cimahi. Penentuan SPALD di Kawasan DAS Cimahi hanya 1 kelurahan yang menggunakan SPALD-T dan 6 kelurahan lainnya. penentuan jenis SPALD di DAS Cimahi ada beberapa analisa daftar penapisan yang memenuhi dan tidak memenuhi persyaratan untuk aturan SPALD-T di setiap kelurahan yang termasuk DAS Cimahi.

Indikator permeabilitas tanah, kemampuan pembiayaan dan kemiringan tanah seluruh kelurahan memenuhi persyaratan. Sedangkan, pada analisa daftar penapisan kepadatan penduduk di DAS Cimahi terdapat 4 kelurahan yang memenuhi yaitu kelurahan Cimahi, Cigugur Tengah, Cibabat, dan Karang Mekar sedangkan Kelurahan Citeureup, Utama, dan Baros tidak memenuhi persyaratan kepadatan penduduk untuk analisa daftar penapisan selanjutnya. Analisa daftar penapisan selanjutnya kedalaman muka air tanah di 2 kelurahan yaitu kelurahan Cimahi dan Citeureup mempunyai muka air tanah aman karena $<25 \mathrm{~m}$ dianggap layak untuk syarat muka air tanah, dan dapat dilakukan analisa daftar penapisan lanjutan, oleh karena itu dari 7 kelurahan yang memenuhi semua kriteria penapisan untuk menggunakan SPALD-T DAS Cimahi adalah Kelurahan Cimahi. 


\section{Daftar Pustaka}

[1] Anggraini, Y., \& Wardhani, E. (2021). Studi Mutu Air Sungai Cibaligo Kota Cimahi Provinsi Jawa Barat dengan Metode Indeks Pencemar. Jurnal Serambi Engineering, 6(1).

[2] Dinas Lingkungan Hidup Kota Cimahi, Dokumen Informasi Kinerja Lingkungan Hidup (DIKPLH Kota Cimahi, 2020) Buku II Laporan Utama Dokumen Informasi Kinerja Lingkungan Hidup Daerah. Kota Cimahi. Jawa Barat, 2020.

[3] E. Wardhani, L. A. Sulistiowati, "Kajian Daya Tampung Sungai Citarik Provinsi Jawa Barat," J. Rekayasa Hijau, vol. 2 (2), 2018.

[4] Fansuri, F. F., Dosen PWK. (2017). Analisis Daya Dukung dan Daya Tampung Lahan Perumahan (Studi Kasus: Kota Cimahi). Fakultas Teknik Unpas.

[5] L. A. Sulistiowati, E. Wardhani, "Kajian Dampak Pembuangan Air Limbah Industri PT. X Terhadap Sungai Cikijing di Provinsi Jawa Barat," Rekayasa Hijau: J. Teknologi Ramah Lingkungan, vol. 2 (1), 2018.

[6] R. Desriyan, E. Wardhani, "Identifikasi Pencemaran Logam Berat Timbal (Pb) pada Perairan Sungai Citarum Hulu Segmen Dayeuhkolot sampai Nanjung Lingkungan,” J. Reka Lingkungan, vol. 3 (1), 2015.

[7] M. Rachmaningrum, E. Wardhani, K. Pharmawati, "Konsentrasi Logam Berat Kadmium (Cd) pada Perairan Sungai Citarum Hulu Segmen Dayeuhkolot-Nanjung," J. Reka Lingkungan, vol. 3 (1), 2015.

[8] A. Arinda, E. Wardhani, “Analisis Profil Konsentrasi Pb di Air Waduk Saguling," Rekayasa Hijau: J. Teknologi Ramah Lingkungan, vol. 2 (3), 2018.

[9] E. Wardhani, S. Notodarmojo, D. Roosmini, Assessment of heavy metal contamination in the water of Saguling Reservoir West Java Province Indonesia, Proceeding, E3S Web of Conferences 73, 06009, 2018.

[10] E. Wardhani, S. Notodarmojo, D. Roosmini, "Heavy Metal Speciation in Sediments in Saguling Lake West Java Indonesia," Int. J. of GEOMATE, ISSN: 2186-2990, Japan, vol. 12 Issue 34 pp 146-151, 2017.

[11] E. Wardhani, S. Notodarmojo, D. Roosmini, "Status heavy metal in Sediment of Saguling Lake, West Java Province," International Journal IOP Conferences Series: Earth and Environmental Science ISSN: 17551315, 17551307, vol. 60, 012035, $2017 \mathrm{~b}$.

[12] E. Wardhani, S. Notodarmojo, D. Roosmini, "Pencemaran Kadmium di Sedimen Waduk Saguling Provinsi Jawa Barat," J. Manusia dan Lingkungan, Pusat Studi Lingkungan Hidup, Universitas Gadjah Mada (PSLH UGM), vol. 23(3), hal. 285-294, 2014.

[13] N. Marlina, W. Brontowiyono, R. Chasna, "Analisis Kualitas Air dan Daya Tampung Sungai dengan Metode Qual2Kw (Studi Kasus: Sungai Code, Yogyakarta)," J. Serambi Engineering, vol. 5(4), hal. 1359-1366, 2020.

[14] R. Christiana, I. M. Anggraini, H. Syahwanti, "Analisis Kualitas Air dan Status Mutu Serta Beban Pencemaran Sungai Mahap di Kabupaten Sekadau Kalimantan Barat," J. Serambi Engineering, vol. 5(2), hal. 941-950, 2020.

[15] Y. Darnas, A. A. Anas, M. A. A. Hasibuan, "Pengendalian Air Lindi Pada Proses Penutupan TPA Gampong Jawa Terhadap Kualitas Air Sumur," J. Serambi Engineering, vol. 5(3), hal. 1165-1176, 2020.

[16] Kementerian Lingkungan Hidup Republik Indonesia, Keputusan Menteri Negara lingkungan Hidup Nomor 115 Tahun 2003 tentang Pedoman Penentuan Status Mutu Air, Jakarta, Indonesia, 2003.

[17] Peraturan Menteri Pekerjaan Umum dan Perumahan Rakyat No 4 Tahun 2017 tentang Penyelenggaraan Sistem Pengelolaan Air Limbah Domestik, 2017.

[18] Peraturan Pemerintah Nomor 22 tentang Penyelenggaraan Perlindungan dan Pengelolaan Lingkungan Hidup, 2021. 